\title{
PANDANGAN NEO SUFISME NURCHOLISH MADJID (Studi Tentang Dialektika Antara Tasawuf Klasik dan Tasawuf Modern di Indonesia)
}

\section{Muninul A6idin}

Fakultas Sains danTeknologi Universitas islam Negeri (UIN)

Jl. Gajayana 50 Telp. -0341-551354 Malang e-mail Muninulabidin@yahoo.com

\section{Abstract}

This research is to describe: (1) the background of emergence of Nurcholish Madjid's thinking about Neo-Sufism. (2) the substance of Neo-Sufism according to Nurcholish Madjid and it's implication to the life of Islamic community. (3) to describe it's existence between classical Sufism and modern Sufism. This research is library research. The data in this research are qualitative data from the books and documents that relate to the topic. The collected data are analyzed by content analysis technique. This research find that two factor cause the emergence of Nurcholish Madjid's thinking about Neo-Sufism: (1) historical and scientific factor that sunni Sufism, philosophical Sufism and modern Sufism are contradicting and blaming each others on their concept. (2) actual factors that is, the emergence of spiritual crisis in the western country and their consciousness to repair it by studying Sufism teaching. Neo-Sufism is the continues of the classical Sufism and modern Sufism thinking, but it try to combine between them. If the classical Sufism stress on spiritual experience, spiritualism, uzlah, wirid, zikir and kasyaf, and take away the profane affairs, and modern Sufism see that uzlah, kasyaf and spiritual experience on classical Sufism as bid'ah and khurafat, Neo Sufism try to combine them by saying that spiritual experience, uzlah, and kasyaf are importance but not to far away from 
profane life. According to Neo Sufism, to be sufi is not throw away profane life but we still can be sufi although to be active in profane life. Nurcholish Madjid's thinking on Neo-Sufism is the consistence of Ibnu Taimiyah-Ibnu Qayyim Al-Juaziyah-Fazlurrahman and Hamka thinking.

Key words: modern sufism, neo-sufism, Nurcholish Madjid

\section{Pendahuluan}

Pada dasarnya tasawuf lahir dalam dunia Islam bukan tanpa sebab, tetapi ada latar belakang sejarah yang menyebabkan kemunculannya. Salah satunya adalah karena kecenderungan pemerintahan Bani Umayyah dan umat Islam yang selalu hura-hura, hidup dalam kemewahan dan kesenangan. Karena itu para ulama yang peduli dengan masyarakat Islam ingin menyelamatkan keberadaan mereka dengan mengajarkan nilai-nilai esoteris Islam, sehingga mereka terhindar dari penyakit hedonisme yang telah melanda umat Islam pada saat itu. Karena itu, tidak mengherankan jika keberadaan tasawuf dapat diterima dengan mudah oleh masyarakat, sehingga dalam waktu singkat, ajaran-ajaran tasawuf menyebar ke seluruh pelosok dunia Islam. (Hanafi, 2002: 45)

Semakin lama, kedudukan tasawuf semakin kuat dan mantap. Ia berkembang pesat bakjamur di musim hujan di berbagai negeri Islam dan banyak melahirkan tokoh-tokoh terkenal, seperti: Syeikh Abdul Qadir Al-jailani, Syeikh Ma'ruf Al-Karakhi, Syeikh Aqil Al-Munji dan Syeikh Hayat bin Qois Al-Harami. Kemudian setelah abad ketiga Hijriyah, lahir pula waliwali besar dari kalangan sufi, seperti Syeikh Junaid Al-Bagdadi, Abu Yazid Al-Bisthami, Imam Syibli, Syamsudin Al-Barazi, Daud At-Tha'i dan sebagainya. Dari tokoh-tokoh tersebut lahir tarekat-tarekat atau jalan pengajaran tasawuf, seperti Abdul Qadir dengan tarekatQadiriyah, Syazili dengan tarekat Syaziliyah dan sebagainya." (Simuh, 1995: 39-48)

Pada awalnya, ajaran tasawuf hanya mengajarkan kepada manusia agar bersikap zuhud, tawakkal, sabar, istiqamah, amanah dan sebagainya. Namun dalam perkembangan sejarahnya, tasawuf telah berubah menjadi sebuah 
ajaran yang penuh dengan pernak-pernik yang tidak dikenal dalam dunia Islam sebelumnya. Tasawuf dianggap berlebih-iebihan dalam beribadah dan menyikapi dunia, sehingga memungkinkan adanya tambahan-tambahan dalam ibadah yang banyak menyimpang dari ajaran agama. Munculnya ajaran tentang asketisme, wahdatul wujud, hulul, dan sebagainya, menjadi salah satu hal yang mendapat banyak kritikan dari tokoh-tokoh pembaharu Islam, di samping ajaran-ajaran esoteris lainnya yang tidak dikenal Islam sebelumnya.

Di Indonesia, kritik terhadap tasawuf semacam ini juga banyak bermunculan. Hamka misalnya mengatakan bahwa sufi yang asal-usulnya bermaksud baik, tetapi akhimya telah mendapatkan banyak tambahan. Maksud mereka hendak memerangi nafsu, dunia dan setan, tapi tak jarang mereka tempuh jalan yang tidak digariskan oleh agama. Terkadang mereka mengharamkan kepada dirinya sendiri barang yang dihalalkan Tuhan, ada yang tidak mau mencari rezeki, menyumpahi harta dan meninggalkan dunia. (Simuh, 1995: 262)

Hamka juga mengkritik bahwa sawuf adalah penyebab macetnya perkembangan Islam. Menurutnya, umat Islam tidak menaruh perhatian terhadap masalah duniawi dan hanya cenderung mencari kesenangan sendiri dengan meneguk kepuasan batin yang ada dalam tasawuf. Dia mengatakan:

"Bekas pendidikan tasazuf semacam itu sangat besar ke dalam dunia Islam. Sekian lamanya kaum muslimin membenci dunia dan tidak meng-gunakan kesempatan sebagaimana orang lain. Lantaran itu mereka menjadi lemah. Akan berkorban, tidak ada yang dikorbankan, karena harta benda telah dibenci. Akan berzakat, tidak ada yang dizakatkan, karena mencari harta dikutuki. Orang lain maju di lapangan penghidupan, sedang mereka mundur. Dan bila ada yang berusaha mencari harta benda, mereka telah dikatakan menjadi orang dunia." (Hamka, 1993: 35)

Ungkapan Hamka di atas bukanlah bermaksud mengkritik tasawuf ansich, akan tetapi untuk mengkritik kecenderungan tasawuf yang ekstrim dan sebagian sikap sufi yang benci dunia, sebab hal itu menurutnya meru- 
pakan penyebab kemunduran Islam dan sekaligus bukan merupakan ajaran Islam. Ajaran tasawuf yang murni pada dasarnya merupakan manifestasi dari ajaran Islam yang benar dan bermanfaat untuk memperbaiki perilaku manusia dari gangguan hidup di dunia ini.

Karena itu, para pembaharu Islam berusaha mencari jalan keluar untuk meluruskan dunia tasawuf agar kembali kepada peran awalnya, yaitu menyelamatkan umat Islam dari krisis kehidupan. Jika pada masa awal Islam tasawuf mampu mengeluarkan umat Islam dari hedonisme dan kemewahan, maka pada saat sekarang, tasawuf harus juga mampu mengeluarkan umat Islam dari kemunduran dan keterbelakangan. Konsep-konsep tasawufklasik, tidak lagi memadai untuk mengajak umat Islam bangkit dari keterbelakangannya. Karena itu, diperlukan konsep-konsep baru yang lebih aplikatif untuk dunia sekarang, sehingga tasawuf memiliki peran yang positif bagi umat Islam pada saat ini. (Hanafi, 2002: 45)

Pemikiran senada juga diikuti oleh para tokoh pembaharu Islam di Indonesia, seperti Hamka. Karena itu, Hamka memperkenalkan konsepkonsepnya tentang tasawuf modern yang dengan konsep ini, dia ingin merombak total ajaran tasawuf dan menyesuaikan ajaran-ajaran itu dengan perkembangan dunia modern (Hamka, 1993: 145)

Akan tetapi konsep Tasawuf Modern yang ditulis oleh Hamka ini, belum cukup memadai untuk mengembalikan peran tasawuf kepada élan vitalnya (Madjid, 1992: 234). Nurcholish Madjid menilai bahwa di satu sisi Tasawuf Modern terlalu kaku dalam menyikapi konsep-konsep tasawuf klasik dan di sisi lain terlalu memaksakan diri untuk menjawab problem moralitas yang dihadapi manusia pada saat ini. Karena itu, diperlukan penyempurnaan konsep tasawuf yang lebih bisa menjawab tantangantantangan dunia sekarang di satu sisi dan di sisi lain menyelamatkan warisan tasawuf klasik yang juga tidak temilai harganya. Beliau memasukkan bidang tasawuf sabagai bagian kajian yang penting. Bahkan ia menganggap, tasawuf adalah salah satu kekayaan budaya Islam klasik yang tak dapat ditinggalkan. (Madjid, 1992: 254)

Ulul Albab, Vol. 9 No. 1, 2008 
Dalan tulisan lain, Nurcholis Madjid mencoba mengkaji tasawuf dari sudut pandang historisitas (kesejarahan) hingga sampai pada pemahamän baru tentang tasawuf tersebut. Dengan jargon klasik, yakni "memelihara yang lama yang baik, dan mengambil yang baru lebih baik", Nurcholis merintis kembali pemikiran kaum pembaru klasik seperti Ibnu Taimiyah dan Ibnu Qayyim al-Jauziyah, dan juga pemikir kontemporer separti Prof. Hamka dan Prof. Fazlur Rahman, apa yang ia namakan sebagai "Neo-Sufisme" (sufisme baru).

Bagaimanakah pandangan Neo Sufisme Nurcholish Madjid ini? Ans bedanya Neo Sufisme Nurcholish Madjid dengan Tasawuf Modern Hamka? Siapa yang mempengaruhi Nurcholish Madjid dengan pemikiran-pemikirannya ini?

Masalah-masalah inilah yang menjadikan peneliti tertarik untuk mengkajinya lebih jauh. Apalagi Nurcholish Madjid adalah seorang tokoh pembaharu Islam di Indonesia yang baru saja wafat, sehingga pemikiranpemikirannya perlu terus dikaji ulang, agar warisan keilmuan beliau yang sangat berharga itu, dapat diwariskan kepada generasi muda di masa mendatang.

\section{Permasalahan}

Dari latar belakang pemikiran di atas, maka permasalahan dalam penelitian ini disusun sebagai berikut:

1. Bagaimanakah situasi dan kondisi yang melatarbelakangi munculnya pandangan "Neo-Sufisme" Nurcholis Madjid? Pertanyaan tersebut dilontarkan untuk mengetahui latar belakang mengapa muncul pandangan Neo-Sufisme Nurcholis Madjid dalam konteks perkembangan Islam dewasa ini.

2. Bagaimana substansi "Neo-Sufisme" menurut Nurcholis Madjid dan bagaimana implikasi pemikiran itu dalam konteks kehidupan umat Islam di zaman sekarang ini? Pertanyaan tersebut didasarkan untuk menge- 
tahui lebih lanjut tentang substansi Neo-Sufisme menurut Nurcholis Madjid dan implikasinya dalam konteks kehidupan umat Islam di zaman sekarang.

3. Di manakah letak persaman dan perbedaan antara sufisme klasik (sufisme lama), sufisme modern (Hamka) dan Neo-Sufisme (sufisme baru) yang dikemukakan oleh Nurcholis Madjid? Pertanyaan tersebut didasar-kan untuk mengetahui lebih jauh tentang letak persamaan dan per-bedaan antara paham sufisme klasik (sufisme lama), sufisme modern dan NeoSufisme (sufisme baru) yang dikemukakan oleh Nurcholis Madjid.

\section{Metode Penelitian}

Jenis penelitian ini metode Library Research atau penelitian pustaka. Penelitian ini ditulis berdasarkan hasil kajian terhadap berbagai bahan pustaka yang relevan, baik yang berupa buku, jurnal, makalah hasil seminar, artikel, majalah, maupun dokumen-dokumen lainnya, yang memuat pemikiran atau pandangan Nurcholis Madjid, khususnya pandangan yang berkaitan dengan konsep "Neo-Sufisme".

Data yang dikumpulkan dalam penelitian ini adalah data kualitatif yang sifatnya "tekstual": yakni berupa statement atau pernyataan serta proposisi-proposisi ilmiah yang dikemukakan oleh Nurcholis Madjid dalam kaitannya dengan konsep "Neo-Sufisme"

Sesuai dengan sifat dan jenis metode yang digunakan, maka sumber utama dalam penelitian ini adalah bahan-bahan pustaka yang relevan dengan obyek masalah yang dikaji. Mengingat si tokoh (Nurcholis Madjid) yang pemikiran dan pandangannya dikaji dalam penelitian ini sudah meninggal ketika penelitian ini dilakukan, maka sumber data hanya murni diambil dari buku-buku, jurnal, dan berbagai sumber dari mass media lainnya yang berkaitandengan masalah Neo-Sufisme yang ditulis oleh Nurcholish Madjid. Setelah itu, peneliti mengolahnya hingga menjadi sebuah konsep.

Sejalan dengan metode yang dipakai, maka teknik pengumpulan data yang tepat untuk dipergunakan dalam penelitian jenis ini adalah teknik 
dokumenter: artinya, data dikumpulken dari dokumen-dokumen seperti buku, cacatan harian, makalah, artikel, dan sebagainya, baik yang sudah dipublikasikan maupun yang masih tersimpan sebagai arsip pribadi si tokoh (Nurcholis Madjid), yang berkaitan dengan pandangannya tentang "NeoSufisme".

Data-data yang telah dikumpulkan itu, selanjutnya dianalisis teknik Content Analysis atau analisa isi. Dengan teknik ini maka data kualitatiftekstual yang diperoleh disortir (dipilah-pilah), dilakukan kategorisasi (pengelompokan) antar data yang sejenis, dan selanjutnya dianalisa isinya secara kritis untuk mendapatkan suatu formulasi yang kongkrit dan memadahi dari pandangan si tokoh sehubungan dengan konsepnya tentang "NeoSufisme", yang pada akhirnya hal ini juga merupakan langkah persiapan untuk mengambil kesimpulan sebagai jawaban terhadap masalah-masalah yang telah dikemukakan.

\section{Hasil Penelitian}

\section{Paparan Data}

\section{a. Sekilas Tentang Nurcholish Madjid}

Nurcholis Madjid berasal dari Jombang, lahir pada tanggal 17 Maret 1939 dan meninggal pada usia 64 tahun. Beliau berasal dari kalangan pesantren, oleh karenanya warna keislaman dalam kehidupannya cukup menonjol, dan tradisi pesantrenlah yang banyak membentuk kepribadiannya. Hal demikian juga terlihat, bahwa selain ia menempuh pendidikan di sekolah rakyat Mojoanyar (pagi), ia juga menempuh pendidikan di Madrasah Ibtidaiyah Mojoanyar (sore), hingga akhirnya ia masuk Pesantren Darul 'Ulum di Rejoso; KMI (Kulliyatul Mu'allimin al-Islamiyah), Jombang. Tampaknya orang tua Nurcholis sangat memperhatikan pendidikan agama anaknya, dan berharap besar terhadap Nurcholis agar kelak kiranya menjadi orang yang "mumpuni" dalam bidang agama. Hal ini terbukti, dengan tekadnya memasukkan Nurcholis Madjid ke Pondok Modern Gontor, Ponorogo, Jawa Timur (Kuswanto, 1994: 42). 
Di Gontor itulah, Nurcholis mulai berkenalan dengan ilmu keislaman secara mendalam. Sebagaimana diketahui, Gontor merupakan pesantern "elite", yang menjadi barometer lembaga pendidikan Islam secara nasional. Di sana banyak diperkenalkan sistem dan metode pengajaran yang variatif dan dinamis, serta kajian keilmuannya yang lebih komprehensif. Dari aspek ini, tampaknya output dari Gontor dapat dijamin kualitasnya. Nurcholis termasuk salah satu yang mendapatkan legitimasi lulusan dari sana, sebagaimana kata Dawam Raharjo: “....tokoh ini adalah didikan pondok modern Gontor, yang di samping mengajarkan ilmu keislaman, juga mengandalkan pengajaran bahasa, yaitubahasa Arab dan Inggris" (Rahardjo, 1993: 37).

Dengan asset ilmu yang diperoleh dari Gontor, Nurcholis mencoba melangkahkan kaki memasuki pintu dunia kampus: IAIN Syarif Hidayatullah di Jakarta. Jurusan yang dipilih adalah sastra dan kebudayaan Islam, hingga akhirnya memperoleh gelar kesarjanaan dari fakultas tersebut pada tahun 1968. Masa kemahasiswaannya banyak diisi dengan kegiatan keilmuan, di samping juga aktif dalam gerakan kemahasiswaan. Di sinilah potensi intelektualitas Nurcholis mulai muncul. Ia tidak hanya sebagai partisipan dalam berbagai kegiatan, tapi "dengung" inteleknya memang sangat vokal dalam seminar dan diskusi ilmiah. Hak demikian cukup mengantarkan ke tampuk pimpinan organisasi kemahasiswaan; ia menjadi ketua umum PB HMI untuk dua periode (1966-1969 dan 1969-1971). Pada tahun yang bersamaan, ia pun diserahi jabatan sebagai Presiden (pertama) PEMIAT (Persatuan mahasiswa Islam Asia Tenggara), tahun 1967-1969; kemudian juga menjadi wakil sekjen IIFSO (InterNasional Islamic Federation Of Students Organizations), tahun 1969-1971.

Paling tidak ada dua isu penting dari gagasan Nurcholis yang konteroversial dari ceramah yang disampaikan di Menteng Raya, yang telah menyebabkan terusiknya pikiran kaum intelektual Islam saat itu, hingga akhirnya terjadi polemik yang berlarut-larut. Pertama, adalah soal, "Islam Yes, Partai Islam No", dan kedua, sebagai kelanjutannya, adalah soal "sekularisasi". Dalam isu yang pertama, mengutip Budhy Munawar-Rachman, 
"....Nurcholis hendak membuat pemisahan antara Islam dan partai Islam. Perjuangan Islam melalui partai Islam hanyalah satu kemungkinan, dan masih ada kemungkinan lain" (Rahman, 1992: 243). Dalam isu yang kedua, mengutip Dawam Raharjo, “....ia menganjurkan sekularisasi sebagai salah satu bentuk liberalisasi atau pembebasan terhadap pandangan-pandangan keliru yang telah mapan....". Maksud sekularisasi adalah memisahkan masalah mana yang betul-betul sakral, dan mana yang betul-betul profan (Rahardjo, 1993: 38).

Karena itu kata Nurcholis Madjid sendiri “....penggunaan kata sekularisasi dalam sosiologi mengandung arti pembebasan, yaitu pembebasan dari sikap penyucian yang tidak pada tempatnya. Karena itu ia mengandung makna desakralisasi, yaitu pencopotan ketabuan dan kesakralan dari objekobjek yang semestinya tidak tabu dan tidak sakral. Jika diproyeksikan kepada situasi modem Islam sekarang, maka sekularisasi itu akan mengambil bentuk pemberantasan bid'ah, khurafat, dan praktek syirik lainnya" (Madjid, 1999: 235). Jadi sekularisasi itu merupakan konsekwensi dari tauhid, kata cendekiawan yang juga mengajar di IAIN Syarif Hidayatullah di tahun 1972 1976, dan peneliti pada LIPI, tahun 1978 hingga wafatnya.

\section{Pandangan Neo Sufisme Nurcholish Madjid}

\section{a. Pengertian Tasawuf}

Dilihat dari asal katanya, ada beberapa teori tentang arti tasawuf. Tasawuf berasal dari kata shafwa, berarti bersih (suci) atau shaffa' (Barmawi, 1991: 13). Sedangkan menurut tasawuf berasal dari kata "shuffah", yaitu bangku yang berada disuatu ruangan di samping masjid Rasulullah di kota Madinatul-Munawwarah (Kalabadzi, 1990: 27). Tasawuf juga dianggap berasal dari kata "shaufanah", yaitu sebangsa buah-buahan kecil berbulu banyak sekali tumbuh di padang pasir di tanah Arab, di mana pakaian kaum sufi itu berbulu-bulu seperti buah itu dalam kesederhanaannya (Barmawi, 1991: 13). Sementara yang lain mengatakan bahwa tasawuf berasal dari kata "shaff" yaitu barisan 
di kala sembahyang. Sebagaimana telah menjadi kebiasaan bahwa orang-orang yang kuat imannya serta suci batinnya, dalam sembahyang selalu memilih di muka dalam berjamaah. Ada juga yang mengatakan bahwa tasawuf berasal dari kata sufiya (shopia) yang memiliki makna "hikmah" yang berarti ilmu atau pengetahuan (Bahrezi, 1990: 1).

Teori-teori tersebut menunjukkan adanya keberagamaan, dan tampaknya berbeda satu sama lain. Namun makna keseluruhannya menunjukkan adanyakesamaan dan saling mengkait. Karena itu secara umum pengertian tasawuf dapat diartikan sebagai bentuk penyucian diri, di dalamnya terkandung makna yang dalam, yakni upaya keras manusia untuk mempererat hubungan vertikal antara dirinya dengan sang kholiq -lebih jauh lagi, dimensi hubungan itu berada di luar orbit lahiri, tapi mengambil tempat dalam dimensinya yang esoteris sesuai dengan sifat Tuhan sebagi Dzat yang Maha Ghaib dari segala yang ghaib. Karena Tuhan merupakan tujuan utamanya, maka segala hal yang berorientasi lahiri (duniawi) dielakkannya. Tujuan agung ini dalam kalangan sufi memiliki istilah yang disebut "Ma'rifat". Perspektif ma'rifat berada pada tempat yang teratas, dan merupakan tujuan pokok bagi para penempuh kesufian. Dengan demikian, berbicara tentang kesufian (tasawuf), maka tidak dapat tidak, kita bahas pula tujuan utamanya, yaitu ma'rifat tersebut. Sedangkan seorang sufi adalah orang yang senantiasa mendekatkan diri kepada Tuhan, dan berpenampilan sederhana dalam hidup di dunia ini.

\section{b. Esensi Neo-Sufisme Nurcholish Madjid}

NeoSufisme merupakan konsistensi pemikiran Nurcholis Madjid dengan pemikir klasik: Ibnu Taimiyah dan Ibnul Qoyyim Al Jauziyah, dan pemikir kontemporer: Fazlurrahman dan Hamka. Karena itu, berikut ini akan dikemukakan definisi Neo Sufisme menurut mereka, berikut beberapa pandangannya yang sebagian besar telah disarikan 
dan dipertegas oleh Nurcholis Madjid (bahasan ini tetap bersentral pada pandangan Nurcholis Madjid).

Ibnu Taimiyah dan Ibnul Qayim disebut oleh Nurcholis sebagai perintis Neo Sufisme memberi pengertian; Neo Sufisme adalah jenis kesufian yang merupakan kelanjutan dari ajaran Islam itu sendiri sebagaimana termaktub dalam Qur'an dan Sunnah dan tetap berada dalam pengawasan kedua sumber utama ajaran Islam itu, kemudian ditambah dengan ketentuan untuk tetap menjaga keterlibatan dalam masyarakat secara aktif. Menurut Nurcholis sekalipun kedua pemikir klasik itu sangat memusuhi sufisme populer, namun jelas mereka adalah kaum Neo Sufisme, malah menjadi perintis ke arah kecenderungan ini. Selanjutnya kata Nurcholis mereka juga mengakui sampai batas tertentu kebenaran klaim sufisme populer; mereka menerima kasyaf (pengalaman penyingkapan kebenaran Ilahi) kaum sufi, tetapi menolak klaim mereka seolah-olah tidak dapat salah (ma'shum) dengan menekankan bahwa kehandalan kasyf adalah sebanding dengan kebersihan moral dari kalbu yang sesungguhnya mempunyai tingkat-tingkat yang tak terhingga.

Menurut Nurcholish bahwa Ibnu Taimiyah dan Ibnu Qoyyim mengaku pernah mengalami kasyaf sendiri. Namun terjadinya kasyf dibawa kepada tingkat proses intelektual yang sehat. Lebih jauhlagi, Ibnu Taimiyah dan para pengikutnya menggunakan keseluruhan terminologi kesufian termasuk istilah salik, penempuh jalan keruhanian-dan mencoba memasukkan ke dalamnya makna moral yang puritan dan etos salafi (Madjid, 1992: 135)

Hal di atas menunjukkan bahwa Ibnu Taimiyah meskipun sangat keras terhadap sufisme, tapi ia masih memandang adanya kebenaran ajaran sufisme dalam batas tertentu. Menurut Nurcholis Madjid Ibnu Taimiyah berpandangan bahwa dalam tasawuf (lama) masih terdapat unsur yang baik yang merupakan hasil ijtihad yang tulus untuk taat kepada Allah dan 
mendekat kepada-Nya, selain juga pada sebagian kaum sufi sendiri ada halhal yang merupakan hasil bid'ah. Hal ini sama saja dengan bidang kehidupan lainnya di kalangan kaum muslim: sebagian berasal dari kitab dan sunnah dengan kemungkinan terjadi ijtihad dalam pemahaman dan pengamalannya, sebagian lagi adalah hasil penambahan yang tidak sah kepada agama yaitu bid'ah. Ibnu Taymiyah memang sangat keras terhadap hal-hal yang ia anggap tidak sesuai dengan ajaran Islam (Qur'an dan Hadits). Kritikkritiknya tidak hanya tertuju kepada sufi saja, tapi terhadap segala aspek yang ia anggap menyimpang dari agama. Terlepas dari sikap kerasnya, kritik dan pandangan Ibnu Taymiyah sering membuat orang takut kepada lidah dan penanya yang memang tajam dan pedas. Kalau ia menyerang atau mengupas soal, bukannya ia sekedar mengejek dan membesarkan dirinya, melainkan dengan keyakinan hendak membersihkan Islam dan dengan cukup alasan membuktikan kesalahan-kesalahan yang dikupasnya (Atjeh, 1998: 105)

Fazlurrahman, disebut oleh Nurcholis Madjid sebagai seorang sarjana yang amat mendalami pemikiran Ibnu Taymiyah dan Ibnu Qayyim, mengemukakan definisi: Neo Sufisme itu mempunyai ciri utama berupa tekanan kepada motif moral dan penerapan metode dzikir dan muroqobah atau konsentrasi keruhanian guna mendekati Tuhan, tetapi isi dan konsentrasi itu disejajarkan dengan doktrin salafi (ortodoks) dan bertujuan untuk meneguhkan keimanan kepada aqidah yang benar dan kemumian moral dari jiwa (Madjid, 1992: 140).

Sementera itu, Hamka, disebut oleh Nurcholis sebagai ulama yang sangat mengenal, dan bahkan menunjukkan konsistensi pemikirannya dengan tokoh pembaru klasik seperti Ibnu Taymiyah dan Ibnu Qayyim (Madjid, 1993: 87). Karena itu, kata Nurcholis, ketika Hamka menulis bukunya yang terkenal, yakni: Tasauruf Modem, ia sesungguhnya telah meletakkan dasar Neo Sufisme di tanah air kita. Dalam buku itu terdapat alur pikiran yang memberi aspirasi yang wajar kepada penghayatan esoteris Islam, namun sekaligus disertakan peringatan bahwa esoterisme itu harus tetap terkendalikan oleh ajaran-ajaran standar syari'ah. Nurcholis juga menunjukkan adanya kontinuitas pandangan Hamka dengan sejarah. Ia jelaskan, 
bahwa sesungguhnya pandangan Hamka ini masih tetap dalam garis kontinuitas dengan pemikiran Imam Al-Ghazali. Bedanya dengan Al-Ghazali ialah bahwa Hamka menghendaki suatu penghayatan keagamaan esoteris yang mendalam tetapi dengan tidak melakukan pengasingan diri atau uzlah, melainkan tetap aktif melibatkan diri dalam masyarakat.

Dalam buku tasawuf modern tersebut, secara tersirat terdapat pandangan tentang prototipe Neo Sufisme (Hamka, 1983: 46). Menurutnya, untuk menjadi sufi saat ini, seseorang tidak harus memasuki suatu tarekat, kemudian berkening-kening dengan guru (syaikh), tidak harus dengan menyepi (uzlah), dan tidak harus dengan metode khusus dalam penempuhannya. Baginya, ajaran tasawuf itu dapat dilakukan oleh siapa saja dan kapan saja, tanpa mengenal kekhususan, karena tasawuf yang benar -sebagaimana juga terdapat dalam kehidupan Rasul dan Sahabat- adalah tasawuf sebagaimana yang dikemukakan oleh Junaid: "Tasawuf adalah meninggalkan budi perangai yang buruk dan mengganti dengan budi perangai yang baik". Dari hal tersebut dapat diketahui, bahwa Hamka sangat mengutamakan tasawuf yang bercorak akhlaqi, dan karenanya ia menolak tasawuf filsafati (teosofi) yang berlebihan maknanya, seperti doktrin wahdat al-wujud dan hulul. Menurutnya, doktrin-doktrin tersebut sangat potensial untuk cenderung syirik atau politheisme yang jelas bertentangan dengan tauhid. Akan tetapi Hamka tidak menolak adanya pengaruh berbagai tradisi seperti; kebiaraan Nasrani, filsafat neo-platonisme, mistik persiadan gagasan-gagasan kaum brahmana. Hal itu menurutnya merupakan suatu kewajaran: suatu budaya yang berinteraksi dengan budaya lain, dan bahkan turut mem-berikan warna kepada aliran tasawuf sepanjang pertumbuhannya.

Namun ia mengisyaratkan bahwa semua pengaruh asing itu tidak bisa dipakai sebagai bahan acuan, sehingga praktis dapat dikatakan bahwa bertasawuf tetap dalam tauhid Islam. Terdapat beberapa kesimpulan pandangan Hamka tentang tasawuf, di antaranya ialah: Pertama menurut Hamka, bertasawuf tidak berarti menolak hidup tetapi bertasawuf haruslah meleburkan diri ke dalam gelanggang masyarakat. Kedua melaksanakan kembali konsep tasawuf pada pokok pangkalnya yaitu tauhid. Oleh karena

Ulul Albab, Vol. 9 No. 1, 2008 
itu tasawuf yang benar adalah seperti yang diungkapkan oleh Junaid AlBaghdadi. Dari sinilah model tasawuf Hamka dapat dikategorikan sebagai tasawuf akhlaq (tasawuf sunni); tasawuf yang berorientasi pada amal perbuatan yang terpuji dan sesuai dengan al-Qur'an dan Sunnah.

Dari beberapa pandangan tentang Neo Sufisme yang dikemukan oleh tokoh-tokoh di atas, dapat diketahui bahwa sebenarnya essensi Neo Sufisme itu adalah al-Qur'an dan Hadits itu sendiri. Nurcholis Madjid menegaskan bahwa apa yang diargumentasikan oleh tokoh-tokoh pemikir di atas menunjukkan bahwa Neo Sufisme ini menegaskan kosistensinya dengan ajaran Islam yang sahih, sebab menurutnya Neo Sufisme itu sejenis kesufian yang terkait erat dengan syari'at dan menekankan perlunya pelibatan diri dalam masyarakat secara lebih kuat daripada sufisme lama. Dengan kata lain menempatkan tasawuf dan syari'at sebagai dua unsur penting dan yang tak terpisahkan dalam Islam. Ditambah lagi Neo Sufisme lebih mencerminkan sikap optimis kepada dunia (atau masyarakat) daripada sufisme lama yang cenderung pesimis terhadap dunia (Madjid, 1993: 130).

Akan tetapi juga tidak menolak beberapa hal penting dalam sufisme lama seperti tentang uzlah, kasyaf dan dzikir (Madjid, 1993: 137). Dijelaskan bahwa sesekali menyingkirkan diri (uzlah) mungkin ada baiknya, jika hal itu dilakukan untuk menyegarkan kembali wawasan dan meluruskan pandangan yang kemudian dijadikan titik tolak untuk pelibatan diri dan aktivitas segar lebih lanjut. Kemudian tentang kasyf ia jelaskan bahwa ini merupakan pengalaman metafisis yang bersifat pribadi dan karena itu tidak berlaku untuk orang lain. Juga tidak boleh diklaim sebagai mesti benar, sebab kebenaran kasyf adalah sebanding dengan kebersihan hati orang yang bersangkutan. Pengalaman kasyf merupakan sumber kebahagiaan pribadi yang tidak ada taranya, namun hal itu tidak dapat disertai orang lain, atau orang lain tidak dapat disertakan di dalamnya. NeoSufisme mengharuskan praktek dan pengalamannya tetap dalam kontrol dan lingkungan ajaran kitab dan sunnah. Tetapi Neo Sufisme menganjurkan dibukanya peluang bagi penghayatan makna keagamaan dan pengalaman yang lebih mendalam

.Ulul Albab, Vol. 9. No. 1, 2008 
yang tidak terbatas hanya kepada segi lahir belaka. Demikian juga tentang konsep dzikir, menurut Nurcholis Madjid semua bentuk sufisme mengajarkan dzikir, yaitu ingat kepada Allah Swt. Dzikir merupakan anjuran Islam yang banyak tersurat dalam al-Qur'an.

\section{Temuan Penelitian}

\section{a. Sebab-Sebab Kemunculan Neo Sufisme Nurcholish Madjid}

Munculnya pemikiran Nurcholish Madjid tentang Neo Sufisme disebabkan karena dua sebab: pertama, sebab ilmiah-akedemis dan sebab aktual. Sebab ilmiah-akademis adalah karena adanya pertentangan antara tasawuf klasik dan tasawuf modern, baik di dunia Islam pada umumnya maupun di Indonesia pada khususnya. Ditegaskan, bahwa dalam sejarah pemikran Islam, antara kedua orientasi penghayatan keagamaan itu sempat terjadi ketegangan dan polemik, dengan sikapsikap saling menuduh bahwa lawannya adalah penyeleweng dari agama dan sesat atau penghayatan keagamaan mereka tidak sempurna (Madjid 1993: 1). Ia juga mengatakan bahwa perpisahan antara dua orientasi keagamaan yang lahiri dan batini itu kemudian mewujudkan diri dalam divergensi sistem-sistem penalaran masing-masing pihak pendukungnya. Maka dari masing-masing lalu timbul cabang ilmu keislaman yang berbeda dari yang lain, bahkan dalam beberapa hal tidak jarang bertentangan, seolah-olah hendak berebut sumber legitimasi dari alQur'an. Maka sebagaimana orientasi keagamaan yang esoteris yang bertumpu kepada masalah-masalah kehukuman itu mengklaim sebagai paham keagamaan (fiqih) dan jalan kebenaran (syari'ah) par excellence, orientasi keagamaan esoteris yang bertumpu pada masalah pengalaman dan kesadaran ruhani itu juga mengklaim diri sebagai pengetahuan keagamaan (ma'rifat) dan jalan menuju kebahagiaan (thariqah) par excellence. (Madjid, 1992: 257)

Nurcholish tidak memihak kedua aliran di atas tetapi ingin memberikan solusi untuk mengkompromikan antara keduanya, yang di satu sisi menghargai pemikiran tasawuf klasik dengan berbagai macam 
- pengalaman ritualnya dan di sisi lain mendukung usaha-usaha tasawuf modern untuk terlibat dalam dunia praktis.

Sebab yang kedua adalah sebab aktual. Nurcholis yang hidup di negeri barat melihat bahwa di negeri barat, krisis itu mendorong timbulnya suatu gejala (fenomena) yaitu arus pencarian makna hidup yang lebih bersifat spiritualistik, sehingga tumbuh bermacam-macam aliran kepercayaan (kultus), sebagian dari hal itu mendorong terjadinya apa yang disebut go east (pergi ke timur), yaitu usaha mencari pola penghayatan spiritual dari Asia terutama India (Madjid, 1993: 68). Gejala ini katanya -dengan mengutip Toffler- hanya dapat diterangkan jika kita melihat gejala negatif masyarakat industri, yaitu kesepian, hilangnya struktur kemasyarakatan yang kukuh dan ambruknya makna yang berlaku. Gejala keterasingan (alienasi) itulah yang menyebabkan orang tertarik kepada aliran kepercayaan atau kultus. Sebab alienasi menimbulkan rasa kesepian yang mencekam yang merindukan persahabatan akrab dan hangat yang mendambakan suatu penjelasan tentang apa dan ke mana hidup (Madjid, 1992: 14).

Di saat dunia mengalami krisis yang menimbulkan dampak adanya gejala alienasi itu, Nurcholis melihat semakin banyaknya orang yang tertarik kepada ajaran tasawuf - suatu mistik yang bercorak Islam. Karena itu ia menyerukan bahwa ajaran yang lebih esoterik ini sekarang harus diberi porsi perhatian yang lebih bear, sehingga dapat diharapkan akan menjadi faktor pengimbang bagi pola kehidupan masyarakat industrial modern yang serba materialistik.

\section{b. Neo Sufisme Nurcholish dan Implikasinya dalam Konteks Ke- kinian}

Sebagaimana dipaparkan di atas bahwa Neo Sufisme merupakan jawaban Nurcholish Madjid terhadap adanya pertentangan tasawuf klasik dan modern di satu sisi dan di sisi lain merupakan jawaban terhadap krisis spiritual yang terjadi di Barat yang hanya bisa didekati dengan pendekatan sufistik. Akan tetapi menurutnya bahwa dunia 
tasawuf yang cenderung bersifat pasif dan isolatif, dalam kerangka neo modernisme harus dirubah menjadi tasawuf yang aktif dan terbuka. Karena itu, Nurcholish Madjid menawarkan dua konsep penting dari Neo sufisme untuk diterapkan dalam kehidupan sehari-hari: (1) Kosmologi Haqgiyah, yaitu suatu pandangan yang optimis terhadap alam dan manusia. Menurut Nurcholish bahwa menjadi seorang sufi tidak harus menghindari aktivitas duniawi dan terlibat aktif dalam kehidupan manusia. Karena itu, dengan konsep ini, Nurcholish menganjurkan bahwa setiap muslim tidak boleh mengisolasi diri dari kehidupan duniawi, tetapi sebaliknya harus terlibat aktif dalam setiap kegiatan hidup manusia, bahkan kalau bisa memimpin manusia. (2) Al-Hanafiyah Samhah: yaitu suatu pandangan yang menganjurkan agar memberikan kemudahan kepada manusia dan bersifat toleran terhadap segala perbedaan yang terjadi dalam segala hal, baik dalam pemikiran, ritual, maupun aktivitas-aktivitas lainnya dalam kehidupan manusia. Karena itu, dengan konsep hanafiyah samhah ini Nurcholish Madjid menganjurkan agar dalam menjalani hidupnya pada saat ini, umat Islam harus senantiasa mengembangkan sikap-sikap yang inklusif, terbuka, toleran dan bisa memahami setiap perbedaan yang terjadi, tidak saling menyalahkan dan tidak saling memusuhi.

\section{Pembahasan}

Sebagaimana dipaparkan pada penjelasan sebelumnya bahwa sejak masa mudanya, Nurcholish Madjid telah memiliki pemikiran yang cerdas dan konstruktif. Salah satu pemikirannya yang kemudian mendasari pemikiran-pemikirannya yanglain adalah tentang modernisme. Dalam pandangan Nurcholish, modern dan maju bukan berarti harus meninggalkan agama dan bersifat kebarat-baratan. Sangat jauh berbeda antara modernisme dan westernisasi. Modernisme berarti sebuah faham yang berorientasi kepada kemajuan dan kemodernan sedangkan westernisasi adalah menempuh jalan kemajuan dengan cara berprilaku kebarat-baratan agar tampak menjadi seperti orang barat. Menurutnya, kita dengan budaya lokal kita sendiri bisa 
menjadi maju dan modern tanpa harus berprilaku seperti orang-orang barat. Karena itu, Nurcholish menentang westernisasi dan menganjurkan modernisasi. Akan tetapi corak modernisme yang ditawarkan oleh Nurcholish Madjid tentu berbeda dengan corak-corak modernisme pada umumnya. Bila modernisme cenderung untuk meninggalkan sesuatu yang lama dan mengambil sesuatu yang baru, maka konsep Nurcholish tentang modernisme tidak demikian. Modernisme menurut beliau adalah menjaga sesuatu yang lama yang baik dan mengambil sesuatu yang baru yang lebih baik, yang kemudian konsep ini disebut dengan Neo Modernisme. Dari sinilah Nurcholish Madjid memulai segala bentuk pemikirannya.

Bagi Nurcholish, yang dalam hal ini berguru kepada Fazlurrahman, bahwa tidak semua peninggalan orang-orang terdahulu itu tidak ada gunanya, tetapi sesuatu yang lama itu sangat banyak gunanya bagi manusia sekarang. Karena itulah Nurcholish menekankan perlunya menelaah turatsturats klasik untuk kepentingan reflektif dan analitik. Proses semacam ini oleh Fazlurrahman disebut dengan proses modifikasi, adaptasi dan penyerapan (Fazlurrahman, 1993: 216).

Metode semacam itu, ternyata tidak hanya dilakukan oleh Nurcholish dalam bidang pemikiran dan filsafat, tetapi juga dalam bidang sufisme. Tidak banyak memang orang yang mengkaji Nurcholish Madjid dari aspek ini. Para pengkaji Nurcholish lebih banyak melihat pemikiran-pemikirannya tentang modernisme, sekularisasi, dan pluralismenya, sehingga sangat jarang yang mencoba untuk mengkaji pemikiran Nurcholish dalam bidang sufisme. Karena itu, meskipun bukan satu-satunya, buku ini cukup memberikan daya dorong bagi para peneliti lainnya untuk lebih dalam lagi meneliti pemikiran sufisme Nurcholis Madjid.

Nurcholish Madjid berada dalam bingkai tasawuf baru yang berbeda dengan konsep-konsep tasawuf pada umumnya, baik tasawuf klasik maupun modern. Tasawuf klasik hanya menekankan aspek-aspek olah batiniyah semata tanpa menghiraukan sama sekali aspek-aspek lahiriyah. Karena itu, tokoh-tokoh tasawur klasik, yang beraliran sunni maupun falsafi, dicap oleh sebagian kalangan modenis sebagai biang kemunduran umat Islam dan 
sebagai penyebab runtuhnya umat Islam dari masa keemasannya. Demikian itu karena tasawuf klasik hanya menekankan ajarannya pada kesucian rohani sehingga kehidupan mereka terlihat sangat sederhana, wara', tawadu' dan zuhud (Hamka, 1984: 19-20). Kehidupan tasawuf lebih runyam lagi ketika masuk di dalamnya unsur-unsur mistik dan seakan-akan mistik telah menjadi bagian yang tidak terpisahkan dari dunia tasawuf. Konsep tentang fana', kasyaf, mabuk, rindu, dan sebagainya telah menjadikan kaum sufi berlomba-lomba memburu akhirat dan meninggalkan dunia. Belum lagi ketika tasawuf pernah terjerembab dalam masa kebobrokan, di mana ajarannya menjadi doktrin agama yang aneh dan berkembang menjadi ajaran yang sesat di kalangan umat Islam, yang disebabkan oleh adanya infiltrasi kultur dan budaya baik dipengaruhi filsafat Yunani, aqidah Majusi, persia maupun tradisi Hindu India. Karena itulah tidak mengherankan jika tokohtokoh modernis mencap sufisme sebagai biang kerok dari kemunduran umat Islam.

Berbeda dengan pernyataan di atas, Nurcholish Madjid justru menyangkal pendapat yang memojokkan sufisme tersebut. Menurutnya, meskipun dalam fakta sejarah sufisme pernah mengalami penyimpangan, namun ia tidak setuju jika tasawuf dijadikan sebagai "kambing hitam" (escape goat) atas kemunduran Islam. Bahkan ia sendiri mengakui dan menghargai jasajasa para sufi terhadap Islam. Sebagai contoh ia tunjukkan ketika umat Islam mengalami kemunduran di bidang intelektual pada abad ke 12 dan ke 13 , gerakan sufilah yang memelihara jiwa keagamaan di kalangan kaum muslim, serta kaum sufi pulalah yang menyebarkan agama Islam keluar daerah timur tengah terutama ke Asia Tenggara termasuk Indonesia dan daerah pedalaman Afrika (Rahardjo, 1992: 103-104). Sikap Nurcholish semacam ini menurut penulis karena dipengaruhi oleh Ibnu Taimiyah yang juga memiliki pandangan seperti itu. Karena diketahui bahwa Disertasi Nurcholish Madjid adalah membahas tentang pemikiran teologi Ibnu Taimiyah sehingga sedikit banyak pemikiran-pemikirannya berpengaruh terhadap Nurcholish. Dia menyebut Ibnu Taimiyah sebagai seorang pemikir besar Islam yang paling kuat argumentaasinya untuk mempertahankan tetap terbukanya pintu 
ijtihad sepanjang masa. Karena itu sekalipun kritik dan kecaman Ibnu Taimiyah kepada sufi begitu keras, namun ia tetap memandang bahwa tasawuf atau sufisme adalah sejenis ijtihad dalam mendekati Allah (Rahardjo, 1992: $6)$.

Sikap toleran Nurcholis ini menurut penulis, semata-mata karena didorong oleh niatnya untuk menjembatani persimpangan jalan antara kaum sufi (esoteris) dan kaum syari'at (eksoteris). Ia memandang bahwa persimpangan atau perpecahan itu dapat meningkat ke batas yang cukup gawat, dan menimbulkan ekses yang bersifat tragis. Sikap ini juga menunjukkan konsistensinya dalam berpikir. Sebagaimana telah dikemukakan di atas bahwa Nurcholish selalu mengusung jargon Neo Modernisme; "Memelihara yang lama yang baik dan mengambil yang baru yang lebih baik." Baginya, seburuk apapun, sufisme tetap memiliki kebaikan yang banyak bagi umat Islam meskipun juga banyak kekurangan. Karena itu, tidak sepantasnya umat Islam begitu saja mengkambing hitamkan tasawuf karena titik hitam yang pernah dilakukannya.

Dari sini dapat dikatakan bahwa pandangan Neo Sufisme Nurcholish Madjid, memiliki sebab historis yang konstan, yang dimensinya menjelma ke dalam konteks kekinian dan memiliki orientasi yang mengedepan. Menurutnya, pemikiran dan perekrutan ajaran tasawuf untuk saat sekarang harus melalui pemikiran yang kritis, kreatif dan selektif sehingga akan menghasilkan konsep yang responsif atau mampu menjawab tantangan zaman dan harus berakar secara mendalam dalam tradisi dan warisan kultural umat Islam yang universal maupun yang lokal. Hal inilah yang menurutnya paling tidak mudah dilakukan karena upaya ini berarti mengangkat trend pemikiran baru yang diambil dari tokoh pemikir klasik dan pemikir kontemporer pendahulunya. Trend inilah yang kemudian dia maksud dengan Neo Sufisme, suatu trend yang perlu perenungan kembali terutama menyangkut sistem dan realisasinya. (Nurcholsih, 1993: 65).

Pemikiran tentang Neo Sufisme sebenarnya bukan sesuatu yang sama sekali baru di tangan Nurcholish, tetapi merupakan kelanjutan dari pemikiran Ibnu Taimiyah dan Ibnu Qayyirn Al-Jauziyah pada masa klasik dan 
pemikiran Fazlurrahman dan Hamka pada masa kontemporer. Posisi Nurcholish sebenarnya adalah sebagai pengembang pemikiran-pemikiran mereka dalam dupia yang lebih kontemporer.

Ibnu Taimiyah dianggap Nurcholish sebagai perintis NeoSufisme karena Ibnu Taimiyah adalah tokoh pembaharu Islam yang meskipun mengkritik habis-habisan dunia sufisme yang sesat dan keluar jalur, tetapi dia tetap mengakui adanya kebenaran dalam sufisme sunni. Hal semacam ini juga dilakukan oleh Ibnu Qayyim Al-Jauziyah dalam pandangannya terhadap sufisme. Sangat sulit sebenarnya meletakkan Ibnu Taimiyah, yang terkenal sebagai musuh bid'ah, tahyul dan khurafat, sebagai perintis Neo Sufisme; karena dalam dunia sufi sangat sarat dengan bid'ah, tahyul dan khurafat. Akan tetapi bagi Nurcholish, justru kritik Ibnu Taimiyah terhadap sufisme yang semacam itulah, yang mengantarkannya menuju perjalanan sufi yang sesuai dengan al-Qur'an dan Sunnah, yang kemudian juga dijadikan sebagai pijakan Nurcholis untuk mengembangkan konsep-konsep Neo Sufisme.

Pandangan Nurcholish tentang Neo Sufisme ini menjadi semakin solid ketika dia berkenalan dengan Fazlurrahman dengan Neo Modernismenya dan Hamka dengan tasawuf modernnya. Nurcholish mengambil prinsipprinsip Neo Modernisme sebagai justifikasi pembenaran terhadap sufisme klasik dan prinsip-prinsip tasawuf modern sebagai aplikasi bentuk tasawuf yang aktual di dunia kontemporer. Perbedaan NeoSufisme Nurcholish dengan Sufisme Modern Hamka sebenarnya sangat tipis untuk dibilang tidak ada. Menurut Hamka, untuk menjadi sufi saat ini, seseorang tidak harus memasuki suatu tarekat, kemudian berkening-kening dengan guru (syaikh), tidak harus dengan menyepi (uzlah), dan tidak harus dengan metode khusus dalam penempuhannya. Baginya, ajaran tasawuf itu dapat dilakukan oleh siapa saja dan kapan saja, tanpa mengenal kekhususan, karena tasawuf yang benar - sebagaimana juga terdapat dalam kehidupan Rasul dan Sahabat - adalah tasawuf sebagaimana yang dikemukakan oleh Junaid: "Tasawuf adalah meninggalkan budi perangai yang buruk dan mengganti dengan budi perangai yang baik" (Hamka, 1983: 3).

Ulul Albab, Vol. 9 No. 1, 2008 
Dalam hal ini seakan-akan tasawuf modern Hamka menolak praktekpraktek tasawuf klasik yang ada dalam dunia tarekat, sehingga rangkaian ritual sufi seperti dzikir, kasyaf, uzlah dan sebagainya tidak diperlukan lagi dalam dunia modern. Dari sinilah model tasawuf Hamka ini dapat dikategorikan sebagai tasawuf akhlaq (tasawuf sunni); tasawuf yang berorientasi pada amal perbuatan yang terpuji dan sesuai dengan al-Qur'an dan Sunnah (Abduh, 1993: 59-60).

Adapun menurut Nurcholis, sekaligus sebagai pembeda dengan pemikiran Hamka, bahwa konsep-konsep tasawuf klasik seperti uzlah, kasyaf, dzikir dan sebagainya tidak apa-apa kita lakukan bahwa sesekali menyingkirkan diri (uzlah) mungkin ada baiknya, jika hal itu dilakukan untuk menyegarkan kembali wawasan dan meluruskan pandangan yang kemudian dijadikan titik tolak untuk pelibatan diri dan aktivitas segar lebih lanjut. Kemudian tentang kasyaf ia jelaskan bahwa ini merupakan pengalaman metafisis yang bersifat pribadi dan karena itu tidak berlaku untuk orang lain. Juga tidak boleh diklaim sebagai mesti benar, sebab kebenaran kasyaf adalah sebanding dengan kebersihan hati orang yang bersangkutan. Pengalaman kasyaf merupakan sumber kebahagiaan pribadi yang tidak ada taranya, namun hal itu tidak dapat disertai orang lain, atau orang lain tidak dapat disertakan di dalamnya. Neo Sufisme mengharuskan praktek dan pengalamannya tetap dalam kontrol dan lingkungan ajaran kitab dan sunnah. Tetapi Neo Sufisme menganjurkan dibukanya peluang bagi penghayatan makna keagamaan dan pengalaman yang lebih mendalam yang tidak terbatas hanya kepada segi lahir belaka (Madjid, 1992; 9).

Dapat dinilai bahwa penulis buku ini, mampu meletakkan Nurcholish sebagai seorang pemikir yang berbeda dengan pemikir-pemikir sebelumnya. Karena itu, posisi Nurcholis digambarkan penulis sangat jelas dalam skema berikut:

\section{Eazlur R:}

Ibnu Taimiyah - Ibnu Qayyim -

Nurcholis Madjid

Hamka

Ulul Albab, Vol. 9 No. 1, 2008 
Dalam skema di atas, Nurcholis dianggaj: sebagai penghujung mata rantai dari pemikir-pemikir sebelumnya, yang dasar-dasarnya diletakkan oleh Ibnu Taimiyah dan Ibnu Qayyim. Kemudian setelah Nurcholish berkenalan dengan dua pemikir berikutnya, yaitu Fazlur Rahman dan Hamka, maka dia menggabungkan pemikiran kedua tokoh itu, hingga akhimya menjadilah konsep NeoSufisme yang dianggap paling relevan untuk dunia kontemporer.

\section{Simpulan}

Dari penjelasan di atas dapat disimpulkan bahwa pemikiran Neo Sufisme Nurcholish Madjid bukan sesuatu yang muncul secara spontan dan tanpa sebab, tetapi merupakan bagian dari rangkaian panjang dari silsilah pemikiran-pemikiran tasawuf sebelumnya, dari tasawuf klasik hingga modern. Namun menurut hemat penulis, penelitian belum sampai kepada konsep yang lebih mendalam tentang Neo Sufisme itu sendiri. Kajian ini lebih bersifat pernetaan terhadap pemikiran tasawuf Nurcholish dibandingkan dengan tokoh-tokoh pemikir lainnya. Adapun dari sisi teoritisnya, konsepkonsep Neo Sufisme Nurcholish Madjid masih belum tercakup secara utuh. Karena itu, mungkin tugas berikutnya diserahkan kepada para pembaca yang tertarik dengan pemikiran Nurcholish, untuk meneruskan dan mengkaji ulang secara lebih mendalam gagasan-gagasan Nurcholish tentang Neo Sufisme ini, sehingga terjadi dialog pemikiran yang lebih komprehensif. Akan tetapi, usaha yang dilakukan dalam penelitian ini, diharapkan cukup untuk dijadikan sebagai pintu pembuka bagi kajian-kajian lainnya tentang pemikiran dan gagasan-gagasan Nurcholish Madjid secara menyeluruh. Diharapkan, dengan tulisan ini dapat menjadi pintu pendobrak bagi para peneliti dan pengkaji muda, untuk mengkaji dan meneliti para pemikir lokal, sehingga gagasan-gagasan mereka yang kaya itu, akan senantiasa hidup dari masa ke masa. 


\section{Daftar Pustaka}

Abduh, M., Al-Manar. 1993. Pemikiran Hamka; Kajian Filsafat dan tasauruf. Jakarta: Prima Aksara.

Hamka, Dr., Prof. 1984. Tasauruf; Perkembangan dan Pemumiannya. Jakarta: PT Pustaka Panjimas.

Madjid, Nurcholis, Dr. 02 Oktober 1992. Beberapa Renungan Tentang Kehidupan Keagamaan di Indonesia Untuk Generasi Mendatang, Naskah Ceramah Budaya. Taman Ismail Marzuki (TIM).

. Dr. April, 1988. Perkembangan Aliran-aliran dalam Islam dan Kaitannya dengan Ukhuwah Islamiyah, Majalah Mimbar Ulama.

1993. Tasaurf Modem. Pustaka Panji Mas. Jakarta.

. 3 Februari 1993. Dewa Air itu dari Prof. Al-Faruqi, Jawa Pos.

- Januari-Maret, 1989. Gagasan Pembahanuan Memerlukan Waktu Panjang, Majalah Tarbiyah IAIN SA. Malang.

. 9 Februari 1993. Lemah Jalankan Ajaran Islam, IPTEK Mundur. Jawa Pos.

. Agustus, 1993. Menuju Masa Depan, Majalah NU "Aula".

. 31 Januari 1993. Reorientasi Wawasan Pemikiran Keislaman; Usaha Mencari Kemungkinan Bentuk Peran Tepat Umat Islam Indonesia di Abad XXI, Makalah Seminar Muhammadiyah dan NU. Universitas Muhammadiyah Yogyakarta.

1993. Seandainya Al-Asy'ari tidak pernah tampil....!, Tabloid Solidaritas IAIN SA. Surabaya.

1993. Sufisme Baru dan Sufisme Lama: Masalah Kontinuitas dan Perkembangan dalam Esoterisme Islam, Makalah Seminar Nasional HMI Cabang Malang, Komisariat IAIN SA. Malang. 
- Oktober, 1992. Upaya Mengobati Alienasi, Eäitut.

Rahman, Fazlur, Islam, Pustaka, Bandung, 1984.

Simuh, Tasaunf dan Perkembangannya dalam Islam, Jakarta, Rajawali Press, 1998.

Abdullah, Samudi, Aralisa Kritis Terhadap Tasaurf, PT Bina Ilmu, Surabaya, 1982.

Atjeh, Aboebakar, H., Dr., Prof., Pengantar Ilmu Hakikat dan Ma'rifat, CV Ramadhani, Solo, 1993.

. Pengantar Sejarah Sufi dan Tasawuf, CV Ramadhani, Solo, 1983.

. Sejarah Filsafat Islam, CV Ramadhani, Solo, 1992.

- Pengantar Ilmu Tarekat, CV Ramadhani, Solo, 1992.

Al-Mannar, M. Abduh, Drs., Pemikiran Hamka; Kajian Filsafat dan Tasaunf, Prima Kasara, Jakarta, 1993.

Hamka, Dr., Prof., Tasauruf; Perkembangan dan Pemurniannya, PT Pustaka Panjimas, Jakarta, 1984.

. Tasauruf Modern, Pustaka Panji Mas, Jakarta, 1993.

Raharjo, M. Dawam, Intelektual Intelegensia dan Perilaku Politik Bangsa, Mizan, Bandung, 1993.

- (editor), Pesantren dan Pembaharuan, LP3ES, Jakarta, 1988.

Rahman, Fazlur, Islam, Pustaka, Bandung, 1984.

Umari, Barmawi, Drs., Sistematik Tasaunf, CV Ramadhani, Solo, 1991.

Ulul Albab, Vol. 9 No. 1, 2008 